\section{A forgotten vulnerable group: Canadian children visiting relatives in the developing world}

Editorial staff of CMAJ recently boasted of championing the health needs of "vulnerable populations." ${ }^{1}$ It has been more than a decade since CMAJ championed better access to safe and appropriate pretravel clinical prevention for vulnerable Canadians travelling overseas. ${ }^{2}$ The most vulnerable group of travellers is children and their immigrant parents who visit friends and relatives living in economically poor countries.

In Calgary, imported cases of malaria are mapped mostly to municipal wards with the highest proportion of immigrant travellers returning from Africa and South Asia. ${ }^{4}$ Epidemiological studies among Canadians consistently identify travellers who visit friends and relatives in economically poor countries as bearing the greatest burden of preventable travel-related diseases such as malaria, hepatitis A and typhoid fever. ${ }^{5}$ Yet, the federal and provincial governments continue to avoid addressing this ongoing problem, in part because of constitutional confusion over responsibility. ${ }^{6}$

Across Canada, provincial governments such as Ontario ${ }^{7,8}$ have removed pretravel clinical prevention from public insurance plans, while at the same time paying physicians in other countries for unregulated care, when travellers seek medical attention for fully preventable or self-treatable diseases. This financing paradox applied to travel medicine's continuum of care perversely promotes cashstrapped high-risk travellers to avoid effective pretravel clinical prevention for life-threatening conditions and vaccinepreventable diseases such as malaria.

However, need for publicly funded pretravel services will grow. The federal government recently announced an ambitious plan to increase immigration to nearly 1 million people over the next three years, ${ }^{9}$ with most coming from developing countries. With changing demographics, there will be increasing travel back to home countries in the tropics and subtropics, opening Canada up to increasing risks of imported infectious diseases. We are likely less prepared now than during the outbreak of severe acute respiratory syndrome in 2003, especially as government policies toward pretravel clinical prevention continue to undermine the building of sustainable local public health and medical capacities.

Provincial governments continue to view pretravel clinical prevention for vulnerable groups, such as travellers who visit friends and relatives in developing countries, as being medically unnecessary. This implies that working-class immigrants and their Canadian children have a "choice" not to leave Canada if they cannot afford all out-of-pocket expenses associated with necessary prevention to visit their home country safely. However, travel is a mobility right under the Canadian Charter of Rights and Freedoms ${ }^{10}$ and not simply a "choice."

Children of immigrants from other Western countries may travel freely to visit relatives, and there are few travel restrictions for overseas relatives to visit Canadians at home. Grandparents and extended family members living in poorer nations in Africa, Asia and Latin America face very different prospects, often being prohibited from visiting Canada because of fears of economic migration. Thus, the only realistic way for these children to keep personally connected with friends and relatives is to travel to destinations with substantial health risks and limited medical care. Therefore, various levels of government neglect to protect Canadian children travelling internationally.

CMAJ states that it champions vulnerable groups. What about taking up the cause of vulnerable children who visit friends and relatives in economically poor countries, whose only fault is to have parents who were born in another part of this world?

\section{Rudy Zimmer MD}

Public health physician, University of Calgary, Calgary, Alta.

Cite as: CMAJ 2018 August 27;190:E1023. doi: $10.1503 / \mathrm{cmaj} .70191$

\section{References}

1. Patrick K, Flegel K, Stanbrook MB. Vulnerable populations: an area CMAJ will continue to champion. CMAJ 2018;190:E307.

2. Keystone JS. Protecting Canadian travellers: prevention is better than cure. CMAJ 2008;178:373.

3. Statement on international travellers who intend to visit friends and relatives: an Advisory Committee Statement (ACS) - Committee to Advise on Tropical Medicine and Travel (CATMAT). Ottawa: Public Health Agency of Canada; 2015. Available: www. phac-aspc.gc.ca/tmp-pmv/catmat-ccmtmv/assets /pdfs/friends-amis-eng.pdf (accessed 2018 Apr. 28).

4. Lee CS, Gregson DB, Church D, et al. Populationbased laboratory surveillance of imported malaria in metropolitan Calgary, 2000-2011. PLoS One 2013;8:e60751.

5. Bui YG, Trépanier S, Milord F, et al. Cases of malaria, hepatitis A, and typhoid fever among VFRs, Quebec (Canada). J Travel Med 2011;18:373-8.

6. Zimmer R. Competing visions for travel health services in Canada. J Travel Med 2018;25: 10.1093/ jtm/tax096.

7. Fact sheet: travel medicine services. Toronto: Ontario Ministry of Health and Long-Term Care; 1998. Available: www.health.gov.on.ca/en/pro/programs/ ohip/bulletins/4317/bul4317b.aspx (accessed 2018 June 17).

8. OHIP coverage while outside Canada: find out what OHIP covers when you're temporarily outside Canada. Toronto: Ontario Ministry of Health and LongTerm Care; 2018. Available: www.ontario.ca/page/ ohip-coverage-while-outside-canada (accessed 2018 June 17).

9. Harris K, Hall C, Zimonjic P. Canada to admit nearly 1 million immigrants over next 3 years. CBC News 2017 Nov. 1. Available: www.cbc.ca/news/politics/ immigration-canada-2018-1.4371146 (accessed 2018 Apr. 28).

10. Canadian Charter of Rights and Freedoms. Part I of the Constitution Act, 1982, being Schedule B to the Canada Act 1982 (UK), 1982, c 11. 2017 Dec. 7. Available: http://laws-lois.justice.gc.ca/eng/Const/ page-15.html (accessed 2018 Apr. 28).

Competing interests: None declared. 